\title{
Which Antibiotic Prophylaxis is Better to Prevent Infections After Transrectal Prostate Biopsy: Single or Combination?
}

\section{Transrektal Prostat Biyopsisi Sonrası Enfeksiyonları Önlemek İçin Hangi Antibiyotik Profilaksisi Daha İyidir: Tek veya Kombinasyon?}

\author{
Cem Şah ${ }^{1}$, Deniz Abat ${ }^{2}$, Adem Altunkol ${ }^{3}$, Mehmet Salih Boğa ${ }^{4}$ \\ ${ }^{1}$ Private Medline Hospital, Urology Clinic, Adana, Turkey \\ ${ }^{2}$ Ministry of Health, İskenderun State Hospital, Urology Clinic, Hatay, Turkey \\ ${ }^{3}$ University of Health Sciences, Adana City Teaching and Research Hospital, \\ Urology Clinic, Adana, Turkey \\ ${ }^{4}$ University of Health Sciences, Antalya Teaching and Research Hospital, \\ Urology Clinic, Antalya, Turkey
}

\begin{abstract}
Introduction: The aim of this study was to compare the effectiveness of three different prophylaxis methods after transrectal ultrasound-guided prostate biopsy.

Methods: Patients who underwent a transrectal prostate biopsy were added to the study. Three different prophylactic antibiotic procedures were applied. In the first group, 62 patients received $500 \mathrm{mg}$ ciprofloxacin orally, 87 patients in the second group received $500 \mathrm{mg}$ ciprofloxacin orally plus one dose of $500 \mathrm{mg}$ amikacin intramuscularly, and 91 patients in the third group received $500 \mathrm{mg}$ ciprofloxacin orally plus one dose of $500 \mathrm{mg}$ amikacin plus $500 \mathrm{mg}$ metronidazole intravenously. Additionally, rectal cleansing with povidone-iodine was performed immediately before biopsy for patients in the third group. Demographic data, antibiotic use within the previous 6 months, comorbidite diseases, and presence of a urinary catheter were compared between the groups according to post-biopsy infection rates.

Results: There were 62 patients in the first group, 87 patients in the second group and 91 patients in the third group. Post-biopsy infection was detected in $5(8.1 \%)$ patients in the first group, $2(2.3 \%)$ patients in the second group and $1(1.1 \%)$ patient in the third group. There were statistically significant differences between the groups according to infection rates $(\mathrm{p}=0.049)$. There were no significant differences between the groups according to the presence of diabetes, urethral catheterization and antibiotic use within the previous 6 months, which are risk factors for infection.
\end{abstract}

Discussion and conclusion: Combination therapy is a more effective approach to prevent biopsy-related infectious complications than single agent therapy.

Keywords: Prophylaxis, Antibiotic, Prostate biopsy

\section{ÖZET}

Giriş ve amaç: $\mathrm{Bu}$ çalışmanın amacı ultrason eşliğinde yapılan transrektal prostat biyopsisinde kullanılan üç farklı antibiyotik profilaksisinin etkinliğini karşılaştırmaktır

Yöntem ve gereçler: Ultrason eşliğinde transrektal prostat biyopsisi yapılan hastalar çalışmaya alındı. Üç farklı antibiyotik profilaksisi uygulandı. Birinci gruptaki hastalar ağızdan $500 \mathrm{mg}$ siprofloksasin aldı. İkinci gruptaki hastalar ağızdan $500 \mathrm{mg}$ siprofloksasin ile birlikte tek doz $500 \mathrm{mg}$ amikasini kas içi uygulama şeklinde aldılar. Üçüncü gruptaki hastalar ağızdan $500 \mathrm{mg}$ siprofloksasin, tek doz $500 \mathrm{mg}$ amikasin ve $500 \mathrm{mg}$ metronidazolü damar içi uygulama yoluyla ald1. Ek olarak 3. gruptaki hastalara biyopsi işleminden hemen önce povidon-iyot ile rektal temizlik yapıldı. Biyopsi sonrası enfeksiyon görülme oranları, grupların demografik özelliklerine, son 6 ay içinde antibiyotik kullanımına, ek hastalıkların varlığına ve sonda kulanımına göre karşılaştırıldı.

Bulgular: Birinci grupta 62, ikinci grupta 87 ve üçüncü grupta 91 hasta vard1. Biyopsi sonras1 enfeksiyon 1. grupta $5(\% 8,1)$ hastada, ikinci grupta $2(\% 2,3)$ hastada ve 3 . grupta $1(\% 1,1)$ hastada 
görüldü. Enfeksiyon oranları açısından gruplar arasında istatistiksel olarak anlamlı farklılık vardı (p: 0,049). Enfeksiyon için risk faktörleri olabilecek diabet varlığı, sonda kullanımı ve son 6 ay içinde antibiyotik kullanımı açısından gruplar arası farklılık saptanmadı.

Tartışma ve sonuç: Transrektal prostat biyopsisiyle ilişkili enfeksiyonları önlemede kombine antibiyotik profilaksisi tek ajan antibiyotik profilaksisine göre daha etkilidir.

Anahtar Kelimeler: Profilaksi, Antibiyotik, Prostat Biyopsisi

\section{Introduction}

Transrectal ultrasound guided prostate biopsy (TRUS-PB) is the most commonly used procedure to obtain tissue for the histological diagnosis of prostate cancer. Although TRUS$\mathrm{PB}$ is a common and increasingly performed procedure in daily practice, this procedure causes infectious complications (6\%). These complications are sometimes severe, and even life-threatening sepsis can be observed (1\%) (1). Thus, antibiotic prophylaxis to prevent infections is generally accepted as a modality. However, the administration schedule of prophylaxis is still controversial. In the past, single agent prophylaxis, especially fluoroquinolones, was recommended. However, recent studies revealed that infection complications after biopsy procedures have been increasing (2). New strategies are needed to prevent infective complications. Because of this, the duration of prophylaxis, using single or multiple agents, adding rectal cleansing with povidone-iodine, and performing rectal swab culture before prostate biopsy have been studies. Additionally, using a transperineal route and/or MR-guided biopsy and decreasing the number of cores are additional controversial issues. In the present study, we tried to compare the effectiveness of three different prophylaxis approaches after trans rectal prostate biopsy. Ciprofloxacin-based prophylaxis compared with ciprofloxacin plus amikacin prophylaxis and ciprofloxacin plus amikacin plus metronidazole with rectal cleansing prevents to infectious complications after biopsy.

\section{Methods}

We performed a retrospective study of patients who underwent a TRUS-PB in two different centers by three urologists between October 2016 and December 2018. All patients received prophylactic antibiotics and applied prebiopsy rectal enema. Three urologists performed three different prophylactic antibiotic procedures according to their own daily practices. Patients were divided into three groups according to prophylactic antibiotic procedures. In the first group, ciprofloxacin $(500 \mathrm{mg}$, orally twice daily) was started 2 days before the biopsy and continued for 5 days after the biopsy. In the second group, patients received ciprofloxacin prophylaxis in the same manner as group 1, and one dose of $500 \mathrm{mg}$ amikacin was administered intramuscularly 30 minutes before the procedure. In the third group, patients received ciprofloxacin prophylaxis in the same manner as groups 1 and 2 and received one dose of $500 \mathrm{mg}$ amikacin plus $500 \mathrm{mg}$ metronidazole intravenously 30 minutes before the procedure. Additionally, rectal cleansing with povidone-iodine was performed immediately before biopsy for patients in the third group.

Patients were excluded from the study if they had taken another antibiotic treatment during the biopsy procedure. Urinalysis and, if necessary, urine culture was performed for all patients before TRUS-PB. A standard 12-core biopsy using an 18-gauge punch needle was performed under local anesthesia with lidocaine for all patients. A disposable singleuse biopsy set was used for all patients.

Readmission to the hospital within two weeks after the biopsy procedure with fever $\left(\geq 38^{\circ} \mathrm{C}\right)$ alone or with lower urinary tract symptoms (dysuria, frequency, urgency) or sepsis was defined as infection-related complications.

Demographic data, antibiotic use within the previous 6 months, comorbidite diseases such as diabetes, hypertension, and atherosclerotic cardiac disease, and the presence of a urinary 
catheter were collected by electronic medical records.

This study has been approved by the Antalya Teaching and Research Hospital local ethics committee. The date 27/08/2020 and Decision no: $13 / 9$.

\section{Statistical Analysis}

Categorical variables were expressed as numbers and percentages, whereas continuous variables were summarized as the mean and standard deviation and as the median and minimum-maximum where appropriate. A chi-square test was used to compare categorical variables between the groups. The normality of distribution for continuous variables was confirmed with the Shapiro Wilk test. To compare continuous variables between groups, Oneway ANOVA or Kruskal Wallis test was used depending on whether the statistical hypotheses were fulfilled. To evaluate the correlations between measurements, the Spearman rank correlation coefficient was used. All analyses were performed using the IBM SPSS Statistics Version 20.0 (IBM Corp, Armonk, NY) statistical software package. The statistical level of significance for all tests was considered to be 0.05 .

\section{Results}

In all, 240 patients were assessed. There were 62 patients in the first group, 87 patients in the second group and 91 patients in the third group. The mean age was $64.1 \pm 6.81$ years in the first group, $63.67 \pm 8.39$ years in the second group and $64.96 \pm 8.93$ years in the third group. The age distribution of the patients in the groups was similar $(p=0.570)$. The mean serum PSA level was $49.67 \pm 178.87 \mathrm{ng} / \mathrm{mL}$ in the first group, $12.65 \pm 21.35 \mathrm{ng} / \mathrm{mL}$ in the second group and $11.06 \pm 16.75 \mathrm{ng} / \mathrm{mL}$ in the third group. The PSA level was higher in the first group than in the other groups, and this difference was significant $(\mathrm{p}=0.001)$. In addition, prostate cancer was detected in 19 $(30.6 \%)$ patients in the first group, $22(25 \%)$ patients in the second group and 31 (34.1\%) patients in the third group. There was no significant difference between the groups according to histopathologic results $(\mathrm{p}=0.414)$. Post-biopsy infection was detected in $5(8.1 \%)$ patients in the first group, $2(2.3 \%)$ patients in the second group and $1(1.1 \%)$ patient in the third group. There were statistically significant differences between the groups according to infection rates $(\mathrm{p}=$ 0.049 ) (Table 1). Infection occured in five patients in the first group. ESBL-producing Escherichia coli (E. coli) was isolated from urine culture of one patient, non-ESBL producing E. coli was isolated from two patients, ESBL-producing Proteus mirabilis was isolated from one patient and Enterobacter cloacae was isolated from one patient in the first group. The one patient, from which non-ESBL producing E. coli was isolated, was treated with seftriakson and the other patients were treated with carbapenems. In the second group, infection occurred in two patients. ESBL-producing E. coli was isolated from one patient, and no bacteria were isolated from the other patient. One patient was hospitalized and treated with carbapenem, and the other patient was treated with seftriakson as an outpatient. In the third group, infection occurred in one patient, and no bacteria were isolated from urine culture. The patient was treated with carbapenem in the hospital. Of the eight (3.3\%) patients who experienced infection, seven patients were hospitalized. Sepsis was not observed in any patient. Of the 34 (14.2\%) patients who had diabetes, one patient in the second group had infection. Of the $13(5.4 \%)$ patients who had a urethral catheter, three patients had infection. The two patients were in the first group, and one patient was in the third group. Of the 12 $(5 \%)$ patients who used ciprofloxacin within the previous 6 months, one patient who was in the first group had infection. There were no significant differences between the groups according to the presence of diabetes, urethral catheterization and antibiotic use within the previous 6 months, which are risk factors for infection (Table 1).

\section{Discussion}

Infections such as urinary tract infection, acute bacterial prostatitis, orchitis, epididymitis 
Table 1. Comparing the parameters that may affected the infection rates between the profilaxy groups

\begin{tabular}{|c|c|c|c|c|c|c|c|c|}
\hline & \multirow[b]{3}{*}{ Level } & \multicolumn{6}{|c|}{ Profilaxy } & \multirow{3}{*}{$p$ value } \\
\hline & & \multicolumn{2}{|c|}{ C } & \multicolumn{2}{|c|}{$C+A$} & \multicolumn{2}{|c|}{$C+A+M$} & \\
\hline & & $\mathrm{N}$ & $\%$ & $\mathrm{~N}$ & $\%$ & $\mathrm{~N}$ & $\%$ & \\
\hline \multirow[t]{2}{*}{ Diabetes Mellitus } & No & 55 & 88.7 & 74 & 84.1 & 78 & 85.7 & 0.725 \\
\hline & Yes & 7 & 11.3 & 14 & 15.9 & 13 & 14.3 & \\
\hline \multirow[t]{2}{*}{ Catheter } & No & 58 & 93.5 & 82 & 93.2 & 88 & 96.7 & 0.530 \\
\hline & Yes & 4 & 6.5 & 6 & 6.8 & 3 & 3.3 & \\
\hline \multirow[t]{2}{*}{ Ciprofloxacin* } & No & 60 & 96.8 & 81 & 92.0 & 88 & 96.7 & 0.273 \\
\hline & Yes & 2 & 3.2 & 7 & 8.0 & 3 & 3.3 & \\
\hline \multirow[t]{2}{*}{ Infection } & No & 57 & 91.9 & 86 & 97.7 & 90 & 98.9 & 0.049 \\
\hline & Yes & 5 & 8.1 & 2 & 2.3 & 1 & 1.1 & \\
\hline
\end{tabular}

* Ciprofloxacin use within the previous 6 months

and sepsis can occur after biopsies. Therefore, antibiotic prophylaxis is strongly recommended. The rates of hospitalization have increased over time because of infectious complications (3).

Fluoroquinolones have a broad effect against rectal flora and a higher penetration rate to the prostate (1). Therefore, fluoroquinolones, specifically ciprofloxacin, are most commonly used for prophylaxis as a single agent. Over time, infection-related complications after prostate biopsy have been rising due to fluoroquinolone resistance (4). In recent years, some prevention strategies have been investigated, such as adding new drugs and/or rectal cleansing, rectal swab culturedirected prophylaxis or decreasing the number of core biopsies via an MR-guided approach. In the present study, we compared single agent ciprofloxacin-based prophylaxis with combination antibiotic prophylaxis. We also assessed the effect of rectal cleansing on the infection rate. We concluded that combination antibiotic prophylaxis with rectal cleansing is associated with a significantly lower infection rate than a single agent ciprofloxacin prophylaxis regimen. The result is compatible with the literature. Marino et al. suggested that the use of any single agent prophylaxis is related to significantly higher infection rates than any combination prophylaxis (5). Similarly, Batura et al. concluded that adding amikacin to single agent ciprofloxacin-based prophylaxis is related to decreased infection rates after biopsy (6). In another study, the authors reported that a high infection-related hospitalization rate under single agent ciprofloxacin prophylaxis was significantly decreased after adding gentamicin intramuscularly. However, over time, increasing bacterial resistance patterns caused a high infection rate (7). We combined rectal cleansing with multiple antibiotic prophylaxis and found better results. That issue has been studied previously, and some studies have reported that the use of povidone-iodine as a rectal disinfectant agent is a safe and effective method to decrease the risk of biopsy-related infections (8).

Targeted prophylaxis according to rectal swab culture may be an alternative method to combination therapy. However, this subject is still controversial. In a study, the authors performed three different prebiopsy prophylaxis regimens: oral ciprofloxacin was performed in the first group, ciprofloxacin plus one dose of intramuscular gentamicin was given in the second group and antibiotic was given according to rectal swab culture in the third group. They concluded that postbiopsy infectious complications occurred less frequently in the ciprofloxacin plus gentamicin performing prophylaxis group than in the other groups (9). According to a recent 
study, performing multidrug prophylaxis or culture-directed prophylaxis decreased hospitalization rates after biopsy due to preventing infectious complications (10). The rate of fluoroquinolone-resistant organisms is 10$30 \%$ according to rectal swab culture in patients who underwent prostate biopsy. However, the rates of infections are 1-17.5\% after biopsy (3). Patients living in some regions in the world have high antibiotic resistance of rectal flora. Targeted or extended antibiotic prophylaxis should be considered for those patients if they underwent transrectal ultrasound-guided prostate biopsy because of high infection risk (11). Performing rectal swab culture is difficult due to lack of consensus in the studies about culture collection timing, to select antibiotics and different agars (12). In addition, some authors have suggested that performing rectal swab culture and offering targeted prophylaxis for high-risk patients significantly decreases infectious complications (7).

The other strategy is to decrease the number of core biopsies using MRI-assisted biopsy. There are also limited studies in the literature, and very low infection rates after MRItargeted prostate biopsy were reported in the current studies. This may be related to the

\section{REFERENCES}

1. Roberts MJ, Bennett HY, Harris PN, Holmes M, Grummet J, Naber $\mathrm{K}$ et al. Prostate biopsy-related infection: A systematic review of risk factors, prevention strategies, and management approaches. Urology 2017; 104: 11-21.

2. Adibi M, Pearle MS, Lotan Y. Cost-effectiveness of standard vs intensive antibiotic regimens for transrectal ultrasonography (TRUS)-guided prostate biopsy prophylaxis. BJU 2011; 110: 86 -91.

3. Borghesi M, Ahmed H, Nam R, Schaeffer E, Schiavina $\mathrm{R}$, Taneja $\mathrm{S}$ et al. Complications After Systematic, Random, and Image-guided Prostate Biopsy. European Urology 2017; 71: 353-65.

4. Noreikaite J, Jones P, Fitzpatrick J, Amitharaj R, Pietropaolo A, Vasdev $\mathrm{N}$ et al. Fosfomycin vs. Quinolone-based antibiotic prophylaxis for transrectal ultrasound - guided biopsy of the prostate: a limited number of cores taken (3). Four basic questions are awaiting answers (12). First, if augmented prophylaxis is necessary which agents should be used? Second, should rectal swab culture be used routinely? If yes, is it truly cost effective? When and what agar should be used? Third, should we changed the route of the transrectal approach to transperineal and MRI-targeted biopsy? Fourth, will molecular methods help us select appropriate antibiotics in the future?

Finally, we concluded that the use of combination antibiotic prophylaxis with rectal cleansing is related to a decreased post prostate biopsy infection rate compared with single agent therapy. However, the risk of increasing antimicrobial resistance over time should be considered. In addition, the standardization difficulty of rectal swab culture, technical difficulty and financial burden of MR-guided biopsy are drawbacks of these techniques.

Conclusion

Combination therapy is a more effective approach to prevent biopsy-related infectious complications than single agent therapy. Additionally, adding rectal cleansing with povidone-iodine to combination therapy leads to better results.

systematic review and meta-analysis. Prostate Cancer Prostatic Dis 2018; 21: 153-60.

5. Marino K, Parlee A, Orlando R, Lerner L, Strymish J, Gupta K. Comparative effectiveness of single versus combination antibiotic prophylaxis for infections after transrectal prostate biopsy. Antimicrob Agents Chemother. 2015; 59: 7273-5.

6. Batura D, Rao GG, Bo Nielsen P, Charlett A. Adding amikacin to fluoroquinolone-based antimicrobial prophylaxis reduces prostate biopsy infection rates. BJU Int 2010; 107:760-4.

7. Woldu SL, Hutchinson RC, Singla N, Hornberger B, Roehrborn CG, Lotan Y. Prospective monitoring and adapting strategies for prevention of infection following transrectal prostate procedures. Urol Pract 2018; 5: 124-31.

8. Grummet J, Pepdjonovic L, Huang S, Anderson E, Hadaschik B. Transperineal vs. transrectal biopsy in MRI targeting. Transl Androl Urol 2017; 6: 368-75. 
9. Elshal AM, Atwa AM, El-Nahas AR, El-Ghar MA, Gaber A, Elsawy $E$ et al. Chemoprophylaxis during transrectal prostate needle biopsy: critical analysis through randomized clinical trial. World J Urol 2018; 36: 1845-52.

10. Womble PR, Linsell SM, Gao Y, Ye Z, Montie JE, Gandhi TN et al. A statewide intervention to reduce hospitalizations after prostate biopsy. J Urol 2015; 194: 403-9.
11. Chung HS, Hwang EC, Yu HS, Jung SI, Lee SJ, Lim DH et al. Prevalence of fluoroquinolone-resistant rectal flora in patients undergoing transrectal ultrasoundguided prostate needle biopsy: A prospective multicenter study. Int J Urol $2018 ; 25:$ 278-83.

12. Chamberland RR. Cutting to the core at the issue: Emerging strategies to reduce prostate biopsy related infections. J Clin Microbiol 2016; 54: 2431-5.

Corresponding author e-mail: ademaltunkol@hotmail.com

Orcid ID:

Cem Şah 0000-0001-5598-4666

Deniz Abat 0000-0001-5801-2061

Adem Altunkol 0000-0002-9300-3694

Mehmet Salih Boğa 0000-0001-7979-8075

Doi: $10.5505 /$ aot.2021.59489 